INTERNATIONAL JOURNAL OF MULTIDisciplinARY RESEARCH AND ANALySis

ISSN(print): 2643-9840, ISSN(online): 2643-9875

Volume 04 Issue 11 November 2021

DOI: 10.47191/ijmra/v4-i11-28, Impact Factor: 6.072

Page No.- 1669-1674

\title{
History of the Uzbek National Puppet Theater
}

\section{Feruza Kobilova}

Senior Lecturer, National Institute of Fine Arts and Design named after Kamoliddin Bekhzod Tashkent,

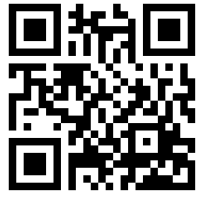
Uzbekistan

ABSTRACT: This article examines the evolution of the formation and development of the art of scenography of puppet theaters in Uzbekistan, the factors of their development during the period of Independence on the example of the National Puppet Theater of Uzbekistan. In shaping the worldview of the young generation, which is the future of our country, modern puppet theater plays a leading role in educating them towards spiritual maturity. Today, a lot of attention is paid to this field of art, and a number of decisions are made for the development of the industry. The main idea of the independence of our country is to help the future generation to grow up spiritually mature, patriotic and educated with all our might. Puppet theater directing, dramaturgy, acting skills, and especially scenography are important with their unique solutions. The reason is that the development trends of modern puppet theater directing and scenography are considered on the basis of three periods, firstly, critical thinking, secondly, religious and mythological themes in the national spirit, and thirdly, analysis of contemporary works.

KEYWORDS: “Big Ivan”, scenography, V.Akudin, S.Sedukhin, constructivism, conceptualism, dynamic aspect, stage space.

\section{INTRODUCTION}

In shaping the worldview of the young generation, which is the future of our country, modern puppet theater plays a leading role in educating them towards spiritual maturity. Today, a lot of attention is paid to this field of art, and a number of decisions are made for the development of the industry. The main idea of the independence of our country is to help the future generation to grow up spiritually mature, patriotic and educated with all our might. Puppet theater directing, dramaturgy, acting skills, and especially scenography are important with their unique solutions. The reason is that the development trends of modern puppet theater directing and scenography are considered on the basis of three periods, firstly, critical thinking, secondly, religious and mythological themes in the national spirit, and thirdly, analysis of contemporary works.

\section{THE MAIN RESULTS AND FINDINGS}

On October 19, 1939, the decision, "Establishment of a puppet theater in the Republic to serve the needs of children in cities, districts and villages" was made in accordance with the Resolution of the Government of Uzbekistan. On December 25, the premiere of the play "Big Ivan" (S.Obraztsov, S.Perobrajensky) took place in a small building. The creators of the play were I.Liozin, N.Rakhimov and M.Efimov. During this period, shows started to co-host by a group of professional performers, a director, an actor and, most importantly, a set artist who has become an integral part of the genre. Now the works have moved to the big stage and the spectacle, along with the director's work, has begun to be addressed by the decoration artist's solution. But even these changes did not pass easily. But even these changes did not pass easily. It has come a long and arduous way from that time to the appearance of the puppet theater of today's potential. Dramaturgy and technical flaws were among the most painful problems of modern puppet theater. Only in the 1960s and 1970s we can observe the process of revival in the theater, directing, dramaturgy and scenographic solutions, the creation of national works and their presentation to the audience. The tandem of director and artist formed in these years has served as the basis for creative collaboration in recent years.

In 1979, the Uzbek National Puppet Theater moved to the Cosmonauts Avenue building. But the technical and dramatic problems encountered in recent years have been a barrier to theatrical success. Puppet theater is a unique aspect of stage design, and none of the scenes used in other performing arts are appropriate for this type of art scene. Therefore, the puppet theater scene should only be adapted to the specifics of the puppet theater. 


\section{History of the Uzbek National Puppet Theater}

The post-independence years were a period of new research for puppet theater. From the 1990s onwards, the role of puppet theater artists began to equalize and even lead the position of director. The theater team opened new pages in the history of puppet theater art during the years of independence. The director Sh.Yusupov, F. Khodjaev, D. Yuldasheva, scenographer V. Akudin, S. Sedukhin, M. Ivanyan and composer A. Ikramov, who worked in 1990-2008, conducted various experiments in the interpretation of classical and modern works, served to restore national, spiritual values. Especially in V. Akudin's creative research, we see that he created a national image based on western and eastern fairy tales. The reason is that nationalism is not only in the form of a puppet, in the elements of clothing or decoration, but in the idea of the work, and the artist is the primary creator in the discovery of this idea. Among such artists, we can list such scenographers as N. Sultanov, $\mathrm{S}$. Sedukhin, S. Kadirov, S. Jiboedov, B. Ismailov, M. Ivanyan. The works of the leading artists V. Akudin and S. Sedukhin, who created their school in the scenography of puppet theater, have made a significant contribution to the development of modern puppet theater scenography. V. Akudin, who devoted his entire life to this art form (1990-2009), created colorful actor-puppets, a unique scenographic solution in all staged performances. His work is based on numerous sketches and researches on the idea of the play, the children's audience, psychology and worldview, depending on the theme. For this reason, performances such as "The Adventures of Fatima" (1987), "Pea Boy" (1996) were loved by a small audience, and the works have not yet left the repertoire of the Uzbek National Puppet Theater. The collaboration of director M. Babadjanov, stage artist V. Akudin, composer A. Nabiev determined the success of this performance. The simplicity of the language of the play, which has a history of thirty years, the bright character of images such as Fatima, the clear and meticulous processing of scenography using colors that have a positive effect on children's psychology in the decoration solution attracts the attention of small audiences. In V. Akudin's drawings, the efforts to create a national image, the combination of traditional and European-type puppets, are clearly reflected in the performance.

"Operating in a creative competitive environment, creating works worthy of a new era, providing a high level of cultural services to children in puppet theaters in many respects depends on the skills, talents and activities of the director and artist. In this regard, when evaluating the activities of the Uzbek National Puppet Theater in the new era, we see instability, a rise and a fall. This was due to the alternation of the director and the lead artists. Qualified actors left the theater. The theater often survived by restoring old performances. New works were rarely staged. However, the Uzbek National Puppet Theater has not lost its leadership in the new era, and has become a model for regional theaters" [1]. The arrival of Sh.Yusupov to the Uzbek National Puppet Theater in 1993 as a director was the starting point of such a rise. His ten-year career as a director at the Bukhara State Puppet Theater promised such a positive rise. His play "Hasan in Search of Happiness" by E. Speransky was successful. At the IV Republican Puppet Theater Festival in Andijan, Yusupov was nominated for "Best Performance of the Year" which led to his election as general director of the Uzbek National Puppet Theater. During his career, the director decorated the theater's repertoire with many successful performances for different genres and different audiences: works such as $V$. Pavlovsky's "Pea Boy", "Olovuddin's Magic Lamp", H. Imonberdiev's "Tent Dream", "Tent Beauty", "Snow Queen" are among them. These performances still occupy a worthy place in the theatrical repertoire. Sh. Yusupov is a director who has made the school of S. Obraztsov, which has a special place in the development of puppet theater in the world. Speaking "in the language of the audience" is a quality that should be in a truly skilled director. As long as the director prepares a play with the belief that "the audience should see it with my worldview", the play will not achieve the success it wants. The audience does not have time to think and analyze during the performance. He has no time for that. He can do this later when he gets home. Therefore, the language and idea of the play must be understood now and only now, in a word, it must be popular"[2].

Working together in a creative team based on the unity, collaboration, tandem and concept of the creative team is another key factor in the success of a performance. At the same time, it is necessary to recognize the creative unity of the successful trio: director Sh. Yusupov, stage artist V. Akudin and composer A. Ikramov.

Yusupov staged the play "Tent Beauty" at the Bukhara Puppet Theater in collaboration with E. Juraev. At the Uzbek National Puppet Theater, the play was re-staged in collaboration with scenographer R. Kamoliddinov. The performance was enriched by the efforts of puppet artist V. Sagadieva, mechanical designer S. Lezhnyov, masters of props A. Andreva.

Another experiment of Sh.Yusupov was the play "Tent Dream", in which he worked with V. Akutin. This solidarity brought an interesting and expressive play to the attention of the audience. In the play, we see a duet of two types of our traditional puppet theater, "Tent Dream" and "Fonus Dream". V.Akudin and Sh.Yusupov made a very interesting proposal for the artistic solution of the play. At the top of the screen was a shadow theater, and at the bottom was a tent puppet, faithful to fantasy traditions. The artist created the puppets for the shadow theater using plastic, not leather, as usual. Live performances have also been used successfully to make the show more lively. Although the artist changed the size of the images of all three stages, he left his appearance and costumes the same. The use of the tent fantasy type provided a unique opportunity to play with lamplight and 


\section{History of the Uzbek National Puppet Theater}

shadow in the performance. The artistic solution of the play is enriched by the efforts of the puppet master V. Sagadieva, mechanical designer S. Lejnyov, master A. Andreeva.

The scenographer must come up with an exact and relevant piece for the performance, based on the artist's play. These pieces should serve to reveal the idea of the play, the inner environment and the state of the characters. Clearly selected items help the audience understand what is happening on stage. The reliability of the item serves to get the viewer the information they need, so it is very important that the scenographer works the items reliably and accurately. As the great Russian director, $\mathrm{K}$. Stanislavsky said: "A true artist should value his art, not himself" [3].

One of the most successful performances was "Pea Boy", which premiered on October 31, 1996. The author of the play is V.Pavlovskie, the stage director is Sh.Yusupov, the stage artist is V.Akudin, the composer is A.Ikramov. "The main requirement of modern scenographic art is to reflect the essence of the work on the stage, in any genre, to show its content in the performance of stage decorations, to help the audience to fall into the atmosphere of the work"[4].

From 1998 to 2000, the Uzbek National Puppet Theater was headed by B. Parmonov, who contributed to the development of puppet theaters in Kazakhstan, Kyrgyzstan, Uzbekistan and Karakalpakstan. From 1998 to 2000 , the Uzbek National Puppet Theater was headed by B. Parmonov, who contributed to the development of puppet theaters in Kazakhstan, Kyrgyzstan, Uzbekistan and Karakalpakstan. In a short period of time, he staged notable plays such as "Gosling", "Snow flower", "Alpomish". Among them, the play " Gosling " is still in the theatrical repertoire due to its ideological solution, puppetry and successful scenographic approach.

In 2003, a great tragedy took place in the history of the Uzbek National Puppet Theater. Most of the decorations and puppets in the theater's repertoire and archives were burned due to the fire in the theater warehouse, causing great moral and material damage to the theater community. This fire caused the loss not only of the decorations of the performance but also of the materials that could be studied, analyzed, researched by today's generation. Even more tragic is the fact that these materials were not fully researched by that time, that scientific pamphlets and books were not sufficiently published, and that much of the information about them was completely lost. The lost sources have now given rise to many questions in scientific research, creating a gap in place of the materials of a certain period. The reason is that the manuscripts and copies were not collected due to the cold attitude of the theater staff at that time, and therefore the sources were completely lost. These two factors complicate our study of the Uzbek National Puppet Theater. Besides, in the first years of independence, the theater was abandoned by many talented artists due to financial problems. During this period, wages were low and the audience problem was very acute. Actors' salaries were not enough to cover their monthly expenses, and playwrights were unable to earn royalties for their plays for years. This factor did not go unnoticed in the creation of puppet theater.

The new general director, M.Ashurova, appointed to the Uzbek National Puppet Theater in 2002, managed to restore the creative atmosphere by strengthening the creative community of the theater with young artists. She tried to enrich the repertoire with new works. As a result of successful attempts, the play "The Adventures of the Mischievous Boy" (based on the story of G. Gulom) was created. It was also important news that puppet theaters had not applied to this work before. The work was shortened by B.Juraev and M.Ashurova's staging and is based on Karavoy's adventures in Sariboy's house. Together with the director M.Ashurova, stage artist M.Ivanyan and puppet master R.lbrahimova, puppets of different appearances were subordinated to the ideological purpose of the play. The play begins with a live performance by the actors. M.Ivanyan used a unique solution in this scene. "The period in which the events take place is clearly visible in the scene. Based on the requirements of the genre, the artist created the scenes of events in a unique way. The melody composed by the talented composer Alisher Latifzoda harmonized with the spirit of the work helped to deepen the image and character, and played a special role in the development and resolution of events"[5].

Theater creators have been experimenting with different performances for many years. In 2003, the Republican seminarmeeting on "Prospects of puppet theater in Uzbekistan in the XXI century" was held in Tashkent. The second part of the Republican seminar-council was organized a scientific-practical conference on "The role of puppetry in inculcating the idea of national independence in the minds of children." A series of lectures on "Education of the younger generation in the spirit of national independence by means of puppetry: research and results" Doctor of Arts, Professor M. Kadyrov on "Peculiarities of puppet theaters in the period of independence", E. Urinov on "Repertoire issues in puppet theaters", Honored Worker of Culture of Uzbekistan Sh. Khaitbaev on "The state of training for puppet theaters" Professor H. Ikramov's lectures on "Puppet Theater Directing: Research and Problems" highlighted the current problems in the puppet theater. The seminar was attended by the Uzbek National Puppet Theater with two performances. One of them was the play "Yana Andersen" from foreign classics. The author and director of the play were D.Yuldasheva, stage artist S.Sedukhin, composer A.Ikramov. "The play is distinguished, firstly, by the perfection and effectiveness of the dramatic source, and secondly, the emergence of vivid images due to the jeweler's precise actions of the actors, the idea of the work, the reflection of the necessary character traits in each character"[6]. 


\section{History of the Uzbek National Puppet Theater}

The master V. Pentyukhov, who created the mechanization of puppets, also depicted the puppets in this play using a Europeanstyle image. The success of this play is due to the fact that the environment created by the stage artist $\mathrm{S}$. Sedukhin showed that the suffering soul is a victim of a period of cruelty and indifference. For example, the effect additives used in it are illustrations depicting natural precipitation (snow, rain, fire). It is a complex stage technical process, a dynamic projection that evokes a strong expressive feeling. The appearance of the indifferent crowd to the grief of others served to reveal the main idea of the work. At the same time, the auxiliary screen decorations behind the main screen made effective use of the joys of the crowds in their homes and the characters rushing towards their families. The mood of the play was enhanced by the lighting of lamps and music in the most painful moments. Although the general artistic solution of the play and the image balance of the puppet images are invented by the director and the artist, the puppet master and puppet designer act independently within this solution and play an important role in embodying the puppet mechanics, costume and finished image. The puppets were made by puppet masters N.Fakhruddinova and L.Mukonina on the basis of S.Sedukhin's sketches. The master of costumes L.Abdullaeva created clothes suitable for the artistic solution of the work.

In the play named "Who Meowed?", staged in 2003, D. Yuldasheva was the stage director and wrote a poem based on the prose work of V. Suteev. The stage designer was N.Yuldasheva, who created a scenographic solution in accordance with the idea of the work. The work was about friendship and loyalty. "In order to show the behavior of the heroes of this musical fairy tale, the versatility of the situation, the stage artist N. Yuldasheva used the "stock" method and carefully prepared them. This style is carried out with special sticks attached to the head and body of the puppets, which increases their ability to move quickly and revive" [7].

In June 2008, Perro's play "Little Red Riding Hood" was staged. Of course, there is not a child who has not heard this tale. Director D.Yuldasheva, stage artist N.Yuldasheva and composer A.lkramov reworked the solution of this fairy tale with a slight change, that is, eventually the grandmother and granddaughter brought up Borivoy. Owl and crow helped them in this work. The show used rope puppets. The puppets were created in the paper-mache method by puppet masters L.Mukonina, N.Fakhruddinova and costume designer L.Abdullaeva. A designer on puppet sketches, V.Pentyukhov, made their mechanization. The consentient efforts of the creative team ensured the success of the performance.

From 2006 to 2008, the director of the theater was Fatkhulla Khodjaev, Honored Artist of Uzbekistan. His plays such as "The Twig Puppet" and "Three Cheerful Pigs" enriched the theatrical repertoire. Since the 2000s, the puppet theater has paid great attention to national colors and elements. Folklore-ethnographic performances were warmly welcomed by the audience. E.Khushvaqtov, a playwright of the Drama Theater, created a play for the puppet theater with the national spirit " The Twig Puppet". Stage director F.Khodjaev, stage artist I.Kurbankulov, composer A.Ikramov presented their works to the audience on March 29, 2008. The puppets are crafted in a chain, creating images of girls, insects, bears and lions. The negative character used a wheelchair designed in the image of a rat. Another important factor is that the decorative bedding used by the girl was in the 'quroq' style, which further enriched the national spirit of the show.

E.Hoffmann's play "Nutcracker" is significant for its psychological-philosophical and "nur-soya" (shady) genre. The play was staged in 2008 on the basis of staging director F.Khodjaev, staging artist A.Chaplenko, choreographer O.Ostanina, D.Yuldasheva. P.Tchaikovsky's music was used in the performance. During the performance, the storyteller Drosselmeyer accompanied the audience. The music of the great maestro Tchaikovsky was so vivid in this wonderful fairy tale written by E. Hoffman that as a result, the spectator did not notice how he fell into the magical world. This genre in modern puppet theater is a professionalized version of the genre of "lantern dream" that exists in our traditional puppet theater. This (shady) genre is done with the help of a flat stage screen, which is unique to modern puppet theater, with the right shooting of light and shadow. So, light plays the basis of this play. Both the director and the scenographer connect all their ideological and artistic solutions to this light, the image and the shadow of the decorative elements.

The play "The Magic Lamp of Alovuddin" (play by A. Chuprin), based on world fairy tales, was also staged on September 12 , 2009, with scenographic solutions and unique images. In collaboration with the director E.Aripova, artist M.Ruzimetova, composer L.Ugay, the classic work, which is familiar and valuable to all of us since childhood, was re-staged with a new idea. Puppet masters L.Mukonina, N.Fakhruddinova, L.Abdullaeva, mechanical master-designer V.Pentyukhov, masterpieces A.Andreeva, G.Vasilevna, S.Vladimorova, Ch.Ruzimetova did their best for the success of the performance. Another factor in the success of the play is that the composer A. Ikramov served as the leitmotif of the play, enriching the Arabic folk dance music in modern pop interpretation.

In 2014, on the basis of H.G.Andersen's fairy tale "Thumbelina", the director D. Yuldasheva, artist M. Ruzimetova, composer A. Ikramov staged a play. The puppets were created by L. Mukonina on the basis of a sketch, and the technique of performance images by N. Fakhruddinova. The puppets and costumes of the live actress-mother are created by L.Abdullaeva. The puppets and costumes of the mother in live performances are created by L.Abdullaeva [10]. 


\section{History of the Uzbek National Puppet Theater}

In recent years, puppet theater decorations have been formed under the influence of currents ranging from realism to postmodernism, as can be seen in the art of scenography all over the world. The difference between theatrical scenography and puppet theater scenography is that while the use of theatrical scenography is overshadowed or, conversely, underused by live performances by actors, puppet theater scenography cannot hide such a shortcoming with any performance. The scenographer of the XXI century must be closely acquainted with all types and currents of fine arts, be masters in the field of mechanization and construction, create and search using these methods. The golden rule in puppet theater scenography is that the artist must feel the norm. Therefore, the work of unskilled artists, which is visible in some regional puppet theaters, affects the quality of the performance and makes the play primitive. The play "Navruz and Spring" is also an experimental performance of young and promising artists. It is a novelty created in collaboration with the stage director H.Akhunov, scenographer M.Ruzimetova and a troupe of talented actors [9].

While studying the activities of the Uzbek National Puppet Theater during the years of independence, we observe many growths (1990-1997) as well as unsuccessful performances. The main reason for this was the lack of creative cooperation and the spirit of solidarity, as the years of the so-called "Reconstruction" of the theater team (1984-1991) were constantly changing. The internal problems of the theater were mainly financial, and the artists were forced to leave the theater by choosing another field. As a result, an important aspect for the art field, the required system has not been developed. However, it is our duty to mention the name of the scenographer artist V.Akudin, who did not oppose his work even in such difficult conditions, and who devoted his whole life to puppet theater. In such circumstances, the theater had to invite a number of directors, but the faithful master devoted every sketch of his work to this place until the end of his life [11].

The work of the amateurs caused the theatrical art to go back a bit. Dramatic issues prevailed. After many years of not being able to collect royalties for their plays in the theater repertoire (2000-2005), the artists did not bring their works to the theater community [12]. Due to such problems, the actors and directors of the theater team chose a play and began to stage performances based on this play. As a result, in the last twenty years, puppet theater drama has "fallen asleep". In the last decade, the Uzbek National Puppet Theater has been using puppets with perfect construction and mechanics compared to regional theaters, however, low-level performances have been on the stage for some time. But today we can see that due to the efforts of the passionate director Sh.Yusupov and his creative team, the theater's repertoire are enriched with high-quality performances that have a theme and idea. In particular, the technical base of the theater has been updated, equipped with new special projectors and stage equipment, which has contributed to the proliferation of such excellent works. However, the theater has its problems, which are primarily a matter of personnel [8]. Especially, solutions such as the formation of a tandem of young directors and artists, the awakening of creative solidarity among young professionals are waiting for us.

As a result of the Resolution of the Cabinet of Ministers of the Republic of Uzbekistan No.218 from 07.08.2014 about "The Renovation of the building of the Republican Puppet Theater and strengthening its material and technical base" and a number of other Resolutions, the Uzbek National Puppet Theater was completely reconstructed, the material and technical base of the theater has been updated in April 2020. In order to ensure the implementation of the Action Strategy for the five priority areas of development of the Republic of Uzbekistan in 2017-2021, the Republican Puppet Theater was renamed the Uzbek National Puppet Theater, taking into account the invaluable contribution to the formation and development of the Uzbek national puppet theater school. From this year, Honored Artist of Uzbekistan Sh.Yusupov has been appointed chief director of the theater. The theater also went online in 2020 for a few months in quarantine. The newly renovated theater opened its 81 st season with the performances "Yurt tumori Tumaris" (playwright Tura Mirzo, director Sh.Yusupov) and "Masha buvi yopgan bogirsoq" (director E.Aripova, stage artist M.Ruzmetova). In addition, the theater hosted the premiere of the play "Legend of Kashmir" based on the story "Song of Kashmir" by statesman, writer Sh.Rashidov, staged by M.Igamnazarova. The author of the staging and stage director was the Honored Artist of the Republic of Uzbekistan M.Igamnazarova, artist M.Ruzmetova.

\section{CONCLUSION}

On December 10-15, 2020, the VI Republican Festival of Young Directors "Debut 2020" was also held online. The 10 most talented participants were selected for it. Pre-recorded performances have been posted on social media. Live performances were organized by participants from Tashkent theaters, and discussions were held on the ZOOM platform. Decree of the President of the Republic of Uzbekistan Sh.Mirziyoev No.PF-6000 dated May 26, 2020 about "The regulations to further enhance the role and influence of culture and art in society" and The Resolution of the Cabinet of Ministers of the Republic of Uzbekistan on the Program of measures to strengthen the material and technical base of state theaters and develop their activities in 20182022 and other regulations related to this activity; increasing the quota for admission to the Uzbek State Institute of Arts and Culture in the field of Acting (puppet theater acting) and Directing (puppet theater directing) from the next academic year, based on the needs of theaters organized in the regions; organization of special part-time departments in the direction of 


\section{History of the Uzbek National Puppet Theater}

puppet theater directing, acting and drama on the basis of the principles of transparency and fairness in order to provide puppet theaters with highly qualified personnel; the task of opening a department of "Puppet Theater Artist" at the National Institute of Art and Design named after Kamoliddin Behzod serves to solve these problems.

\section{REFERENCES}

1) Kadirov M. Peculiarities of the activity of puppet theaters in the period of independence. // Theater. T; 2004/1.

2) Obraztsov S. "My profession". M., Art. 1950.

3) Kadirova D. "Uzbek scenography of the XX century" T., Art. 2009.

4) Rahmatullaeva D. "The Mischievous Boy" .// Theater 2004/1.// p.24.

5) Ikromov H. "Puppet theater directing: research and problems" // Theatre. 2004/1//. 22-p.

6) Shayhova E. "Who meowed?" // Theater 2003/1.

7) Gensitskaya N., Klen N. "The basis of the puppet sculpture". 2009 / -88p .: il- (Series "History of a single puppet")

8) Kodirov M., Kodirova S. "History of puppet theater". T., Talqin. 2006.

9) Abdumalikova Z. "The Adventures of Fatima”. // Theater. T., 2014/1.

10) Demmeni E. "On the stage”. L.; M., Art, 1949

11) Obraztsov S.V. "Actor with a puppet". M.; L., Art, 1938

12) Fedotov V. "Puppet theater technique". M., Art, 1953

13) Sayfullaev, N. (2021). The Name Of Our Country Will Be Praised By The Followers Of Kamoliddin Bekhzod. The American Journal of Social Science and Education Innovations, 3(04), 402-408.

14) Sayfullaev N. (2019). Current Issues on Fine ARTS Education: Continuity and Prospects for Development. Religación, 4 , 192-194.

15) Kurbanova D. A. (2016). ANCIENT PEARLS IN GREAT WORLD MUSEUMS WHICH BELONG TO THE HISTORY OF UZBEKISTAN AND LEARNING THEM. Couuocopepa, (3), 55-61. 